Proceedings of the 2012 Winter Simulation Conference

C. Laroque, J. Himmelspach, R. Pasupathy, O. Rose, and A. M. Uhrmacher, eds.

\title{
AN AGENT-BASED MODEL OF THE BATTLE OF ISANDLWANA
}

\author{
Chris Scogings \\ Ken Hawick \\ Massey University \\ Private Bag 102-904 North Shore \\ Auckland 0745, NEW ZEALAND
}

\begin{abstract}
Agent-based models have been used to capture and analyze the essential behaviors of combat units although the number of agents used has been fairly low. We experiment with a microscopically detailed agent model in which over 20,000 soldiers are represented individually (one agent per soldier) in a simulation of the Battle of Isandlwana in 1879.

We describe how a rule based model can be specified for soldiers on both sides and how it can be specialized for different skill sets and fighting capabilities of soldier agents belonging to particular units. We address some of the challenges of programming a model consisting of large numbers of agents. We demonstrate that our model provides a simulation of the battle with considerable historical accuracy and then go on to show how the same model can be used to demonstrate a plausible alternative to history.
\end{abstract}

\section{INTRODUCTION}

On 10 January 1879 the British Empire invaded Zululand, a small African kingdom in what is today the province of KwaZulu-Natal in South Africa. The Zulus possessed a disciplined and well-trained army but were not equipped with modern firearms. On 22 January 1879 at Isandlwana Hill, the Zulu army comprehensively defeated a British force of almost 2,000 men and drove the invaders from Zululand. It was the greatest defeat ever suffered by the British army against a force armed only with traditional weapons.

In his book "Artificial War", Ilachinski (2004) outlines the problems that can arise when simulating combat situations using traditional mathematical models such as the Lanchester Equations (Lanchester 1916). Ilachinski then goes on to demonstrate the strengths of agent-based models in such simulations. Agent-based models have also been analyzed by others (Thengvall and Glover 2009) and have been found useful in a range of military applications from an exploration of squad size (Cioppa, Lucas, and Sanchez 2004) to their use as a tool for naval concept developers (Cares 2002). Military history and the analysis of previous battles and conflicts is another obvious area that lends itself to simulation by agent-based models for example an agent-based model has been successfully used to analyze the Battle of Trafalgar (Trautteur and Virgilio 2003).

Agent-based models (Macal and North 2006) are often used to investigate complex systems (Standish 2001) from a statistical perspective. Agent-based modeling has been used in many different application contexts including crowds (Kaup et al. 2007), vehicles (Gerdelan 2011; Thangiah et al. 2001), robots (Settembre et al. 2008), predator-prey models (Hawick et al. 2008; Scogings and Hawick 2008; Jim and Giles 2000), biological bacteria movements (Garcia et al. 2011); flocking agents (Husselmann and Hawick 2011) such as the "boids" model (Reynolds 1987), as well as military systems.

In such work typically many different initial conditions are drawn from a random set and trajectories through the model space are sampled by running the simulation. This approach is successful in identifying attractors (Procaccia 1988) in the model configuration space. Emergent spatial patterns (Caristi et al. 1992) of surprising complexity are also often identified in this manner. In this present work we are able to work 


\section{Scogings and Hawick}

from a known initial configuration of agents and can perturb this to explore alternatives. In the course of the simulation we also find certain agent patterns such as Zulu battlefield formations to be an emergent and seemingly inevitable property of the microscopic rules.

In this article we present an agent-based model of the Battle of Isandlwana. Based on extensive research into techniques for increasing efficiency in agent-based models (Hawick et al. 2008) our simulation contains an agent for every individual involved in the Battle of Isandlwana (over 20,000 agents). Previous models have deployed a much smaller number of agents - for example there are 60 agents (ships) in the agent-based simulation of the Battle of Trafalgar (Trautteur and Virgilio 2003). Our model is used to simulate the historical Battle of Isandlwana and the historical outcome is achieved. The model (with the same parameter settings) is then used again to demonstrate that an alternate initial deployment by the British forces may have led to a different outcome.

A brief description of the historical battle is provided in Section 2. We then describe the agent-based model in Section 3. The results of the historical simulation are presented in Section 4 and an alternative scenario is presented in Section 5. A summary and some ideas for future work are discussed in Section 6. There is a full order of battle available in the Appendix.

\section{THE BATTLE}

The main source for the details in this section is "The Illustrated Guide to the Anglo-Zulu War" (Laband and Thompson 2000).

The Zulu kingdom maintained a conscription system whereby all males of about 18 years old were grouped into regiments (Zulu: amabutho). Each regiment thus consisted of men of about the same age and was available for use as the king saw fit. While men were not permanently on military service, the system ensured that the amabutho could be rapidly formed and deployed. Regiments were usually disbanded when the men in them reached an age of about 35-40. Weapons included javelins, the short stabbing spear ( $\mathrm{kklwa}$ ), the knobkerrie (short knobbed club) (iwisa) and cow-hide shield. Firearms were available but were not standard issue and men were not trained in their use. Most firearms were elderly and unreliable muskets with scant supplies of powder and shot. The standard Zulu military formation was known as the "horns of the ox" in which the "chest" (or center) consisting of veteran amabutho advanced slowly while the "horns" (or wings) of younger amabutho moved rapidly to outflank the enemy position.

The forces invading Zululand in 1879 consisted of British regular infantry (the 24th regiment) supported by South African (colonial) mounted units. All these forces are referred to as British in this article. Infantry were armed with the single-shot Martini-Henry Mark II .450 caliber rifle and the colonial mounted units usually carried Swinburn-Henry or Snider carbines. Supplementing the British forces was the Natal Native Contingent (NNC) comprising local African men (often recruited with promises of captured cattle). They were poorly armed and ineffectually trained and, because the British were unwilling to issue them with modern firearms, only one in ten men carried an obsolete muzzle-loader and the rest were armed with traditional spears and shields. Further details are available in (Thompson 2006).

On 20 January 1879 the British column under Lord Chelmsford made camp at the foot of Isandlwana Hill. No reconnaissance was conducted and no trenches or defenses were constructed. The bulk of the Zulu army (about 20,000 men) was less than 20km away but the British consistently under-estimated Zulu capabilities. On the next day about 2,000 Zulu staged a diversion which successfully caused Chelmsford to split his forces - sending the bulk of his men on a fruitless pursuit of the far more agile Zulu and leaving a smaller group to defend the camp.

On the morning of 22 January, the Zulu army descended on the camp. The British were caught with no prepared defenses and with part of the camp garrison (the right flank in Figure 1) on its way to reinforce the pursuit of the Zulu diversion. Consequently the British line was thinly spread out and formed up in open skirmish order ( $3 \mathrm{~m}$ to $6 \mathrm{~m}$ between men).

For some time the Zulu center was pinned down by heavy fire from the British lines while the Zulu wings moved to outflank the British line. The British infantry then ran short of ammunition due to the difficulties 


\section{Scogings and Hawick}

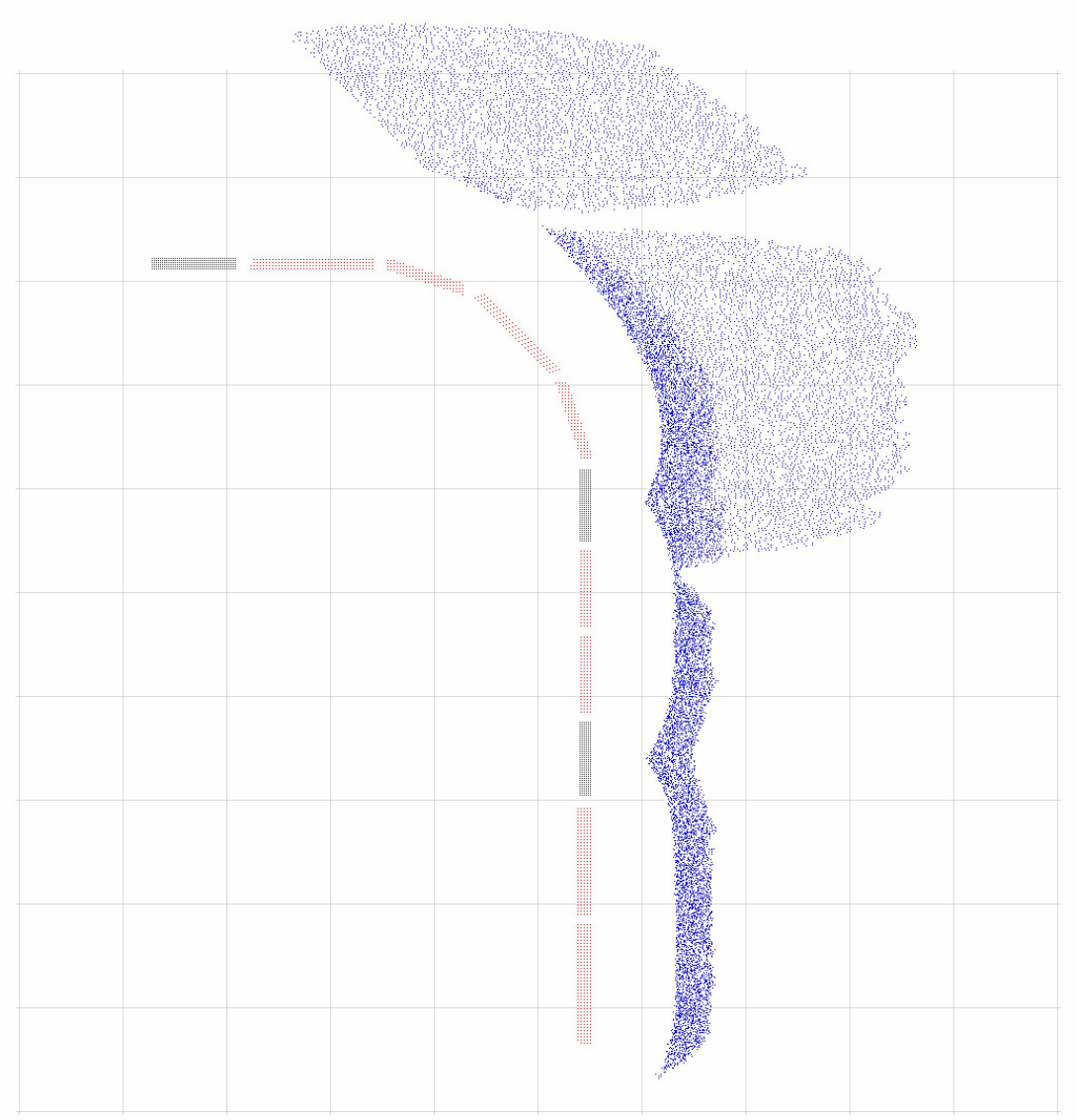

Figure 1: Time step 480 of the Historical Scenario: the Zulu (blue) have closed to within firing range of the British (red). The Zulu center and left wing are bunching as the leading ranks drop prone to avoid the British fire but the rear ranks continue to press forward. The Zulu right wing is still spread out and closing. The Zulu have advanced closest to the NNC (gray) positions as these troops have very few firearms.

of supplying the spread out formations and fire began to slacken. The Zulu seized this opportunity to close with the British line, charging into the British formations and initiating hand-to-hand combat. Several of the NNC companies broke and fled which further weakened the line. British and NNC troops were cut down where they stood or pursued as they fled. About 1,300 of the 1,700 British and NNC troops involved were killed. The Zulu army of just under 20,000 lost at least 1,000 killed and suffered another 2,000 to 4,000 wounded - many of whom would have died later due to the absence of medical care.

\section{THE MODEL}

The main objective of this experiment was to construct an agent-based model that comprised several thousand individual agents and use it to successfully simulate an historical battle. The Battle of Isandlwana was chosen as a suitable subject because there has always been great interest in why the British were defeated and various alternative scenarios have been suggested - for example, what if the British forces had formed a compact square? 


\section{Scogings and Hawick}

In addition to this, the battle provides the ideal subject for testing a large-scale agent-based model for the following reasons:

- 20,000 agents provided a number that was substantially larger than most other models but was not excessively high.

- Terrain effects played no part in the battle. Future work could incorporate the effects of hills, trenches, forces hidden from view, etc.

- Historical troop movements were relatively simple: Zulu forces advanced directly towards the British (with some attempt at flanking movements), NNC units retreated or fought if trapped and British troops remained mostly in static formations (although some individuals escaped at the end).

- Very little variation in the weapons employed: British used rifles (and carbines) and Zulus and NNC had none. In fact the British did use two 7-pounder RML Mark IV mountain guns but these were ineffective with shrapnel-shot (due to low muzzle velocity) and are not simulated in the model. The British also deployed one Hale's rocket battery but this had no effect at all on the advancing Zulu forces and is also not simulated.

- Detailed knowledge of troop strengths and positions was available.

In summary, these points ensured that the agent-based model required to simulate the battle need not be overly complicated, allowing the authors to focus on the design challenges inherent in constructing a model consisting of over 20,000 agents. Every man who took part in the battle is represented by an individual agent in the model. They are all placed in their correct formations across the battlefield (see Figure 1). Other models use far fewer agents - for example, the Battle of Trafalgar (Trautteur and Virgilio 2003) uses one agent per ship with a total of 60 agents.

Each agent has a small set of simple rules and every time step each agent attempts to execute one rule. The rules are provided (and executed) in priority order. Thus every agent always attempts to execute rule 1 first. However most rules carry conditions and can only be executed if the conditions are met. If the condition for rule 1 is false, the agent attempts to execute rule 2 and so on down the list. This is summarized in Algorithm 1. Some details have been omitted in order to enhance clarity.

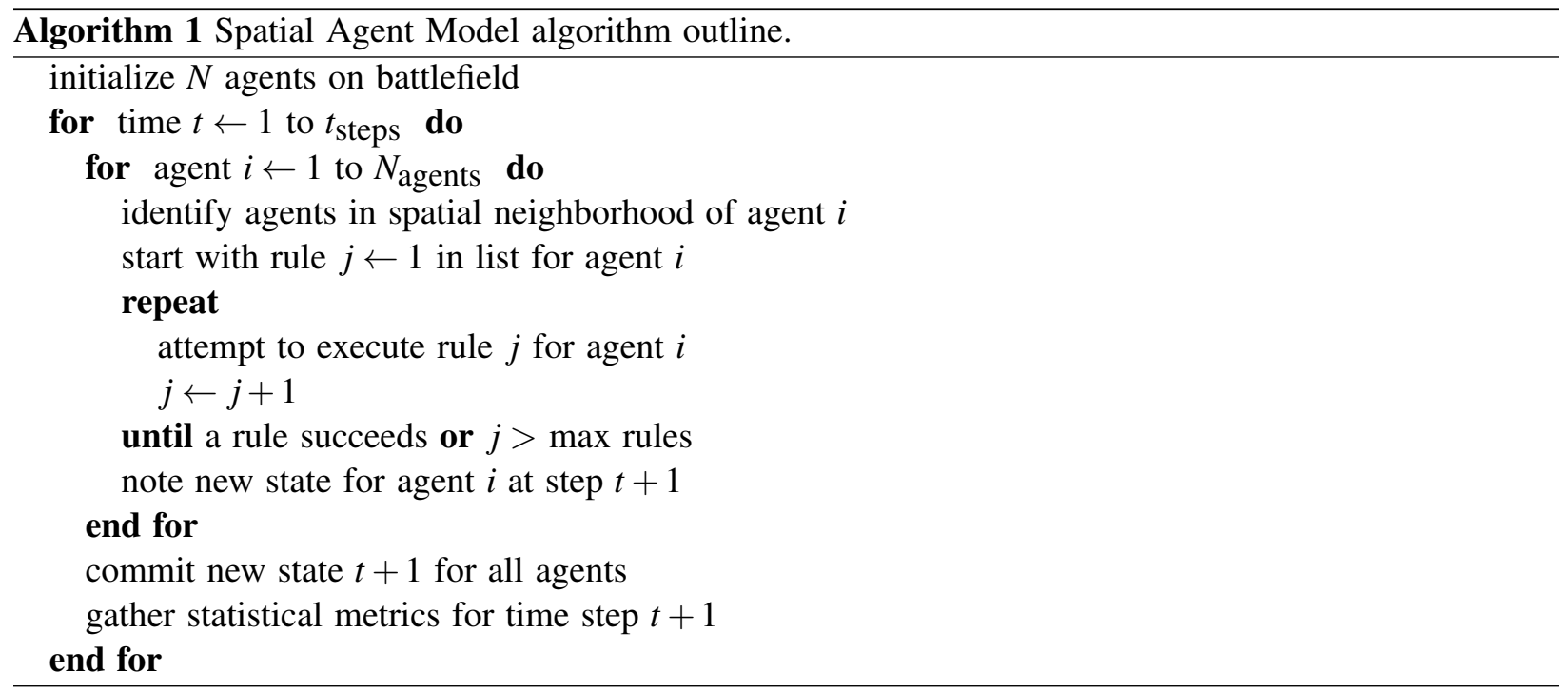

Note that it is possible that an agent will do nothing if the conditions for every rule in its rule set are not met. The specific detailed rules for British, NNC and Zulu agents are given below.

Rules for British (and colonial) agents: 


\section{Scogings and Hawick}

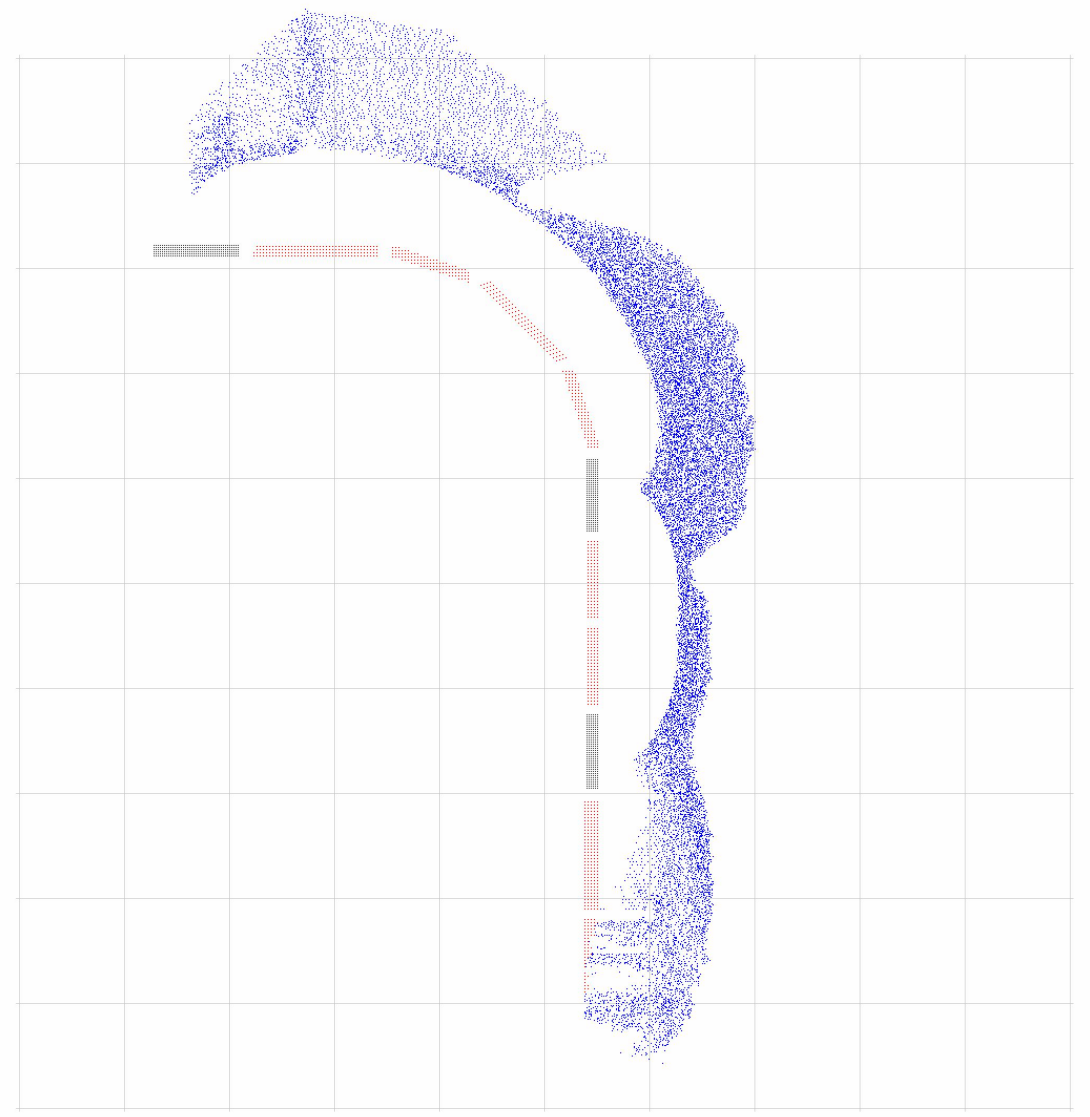

Figure 2: Time step 680 of the Historical Scenario: British troops (red) on the right flank (furthest from the supply source) are the first to run short of ammunition and the Zulu (blue) rush the position. The Zulu right wing is also closing with the NNC (gray) on the extreme left of the British line.

1. if Zulu is adjacent - then hand-to-hand combat

2. if rifle loaded and Zulu in range and - then fire

3. if rifle not loaded and ammunition available - then load rifle

British rifle fire accuracy increases as the range to the target is reduced. At long range (100 pixels) there is a zero chance of hitting the target. This increases to a 95\% chance of hitting an adjacent target (distance of 1 pixel). British have no move rule. Historically British troops did fall back but maintained formation and were eventually killed by overwhelming numbers of Zulu. Some mounted colonial troops managed to escape.

British agents can only reload their rifles if ammunition is present. The model assumes an ammunition source (the camp) at the rear center of the British line. Formations that are too far from this point have a less than $100 \%$ chance of restocking their ammunition. Accounts of the historical battle agree that troops ran short of ammunition and it was the slackening of rifle fire (particularly on the British right flank) that gave the Zulu the opportunity to successfully assault the line. The model successfully simulates this situation and the destruction of the right flank is depicted in Figure 2.

Rules for Natal Native Contingent (NNC) agents: 


\section{Scogings and Hawick}

1. if Zulu is adjacent - move away from Zulu

2. if Zulu is adjacent - then hand-to-hand combat

One in ten men of the NNC were armed with muskets but these were generally ineffective. The NNC rules appear to contradict one another but this is because Rule 1 (move away from Zulu) may fail due to crowding. If an NNC agent in the front rank is adjacent to a Zulu it will first try to move away but this is often not possible due to the other NNC agents around it, in which case it will move onto Rule 2 and initiate hand-to-hand combat.

Rules for Zulu agents:

1. if British or NNC adjacent - then hand-to-hand combat

2. if other Zulu adjacent - then spread out

3. if British or NNC within "attack range" - then charge directly at the enemy

4. move according to preset movement vector

British fire may produce one of three outcomes: A miss which has no effect; a hit which immediately destroys the Zulu agent that has been hit; and a "near miss" which causes the Zulu agent to seek cover and drop into a prone position. While prone the agent will not execute any rules. A Zulu agent will remain prone for 15 to 20 time steps.

Each Zulu regiment is provided with an initial movement vector. This may direct the regiment straight towards the British line (in the case of the Zulu center and left wing) or cause the regiment to initially swing around the British line (in the case of the Zulu right wing). All individual Zulu agents are provided with the preset vector of their regiment. Note that if Zulu agents are close enough to the enemy, vector movement (Rule 4) will not be used as it will be replaced by the direct charge (Rule 3).

In common with many agent-based models much time is taken up by agents locating the nearest agents of each type. For example, every time step, each British agent must locate the nearest Zulu agent (to fire at) and every Zulu agent must locate other Zulus (to move away from) and British (or NNC) agents (to charge towards). This is a common problem with models, for example see the Boids model (Reynolds 1987), and is usually the most important factor limiting the number of agents in the model.

In order to achieve the required efficiencies for the large number of agents in our model it was necessary to reduce the number of times that each agent individually searches through all the other agents looking for the nearest neighbor. This was achieved by using discrete coordinates and preloading a list of location offsets sorted by distance (from nearest to farthest). For example the first entries in this list are: [1, 0, 1.0], $[0,1,1.0],[-1,0,1.0],[0,-1,1.0],[1,-1,1.4],[-1,-1,1.4],[1,1,1.4],[-1,1,1.4], \ldots$ where each element contains [x-offset, y-offset, distance]. An agent sequences through the list checking the locations calculated by adding the offsets to its own location. The search can be terminated as soon as it locates an agent of the required type. The distance to this located agent is immediately available from the list element, thus precluding the need for time consuming distance calculations. Further details of maximizing efficiency in hand-coded agent-based models can be found in (Scogings, Hawick, and James 2006).

\section{THE HISTORICAL SCENARIO}

The model was used to simulate the historical battle. All British and NNC agents were individually assigned to their correct formations and the formations were placed in the positions depicted in (Laband and Thompson 2000). The Zulu agents start by approaching the British positions from the east.

Maximum rifle range was about $350 \mathrm{~m}$ but effective rifle fire would only stop a determined enemy force at about $100 \mathrm{~m}$. At approximately this range, the Zulu advance stalled as the leading Zulu ranks were either destroyed by heavy British fire or dropped prone to present a smaller target. Descriptions of Zulu regiments dropping prone to avoid fire appear regularly in eyewitness accounts, for example:

"The guns fired hard at the uMcijo first, they fired sufficient times for this regiment to lie down like grass in a strong wind" Luke Zungu, Zulu survivor, 17 December 1935 in (Laband and Thompson 2000). 


\section{Scogings and Hawick}

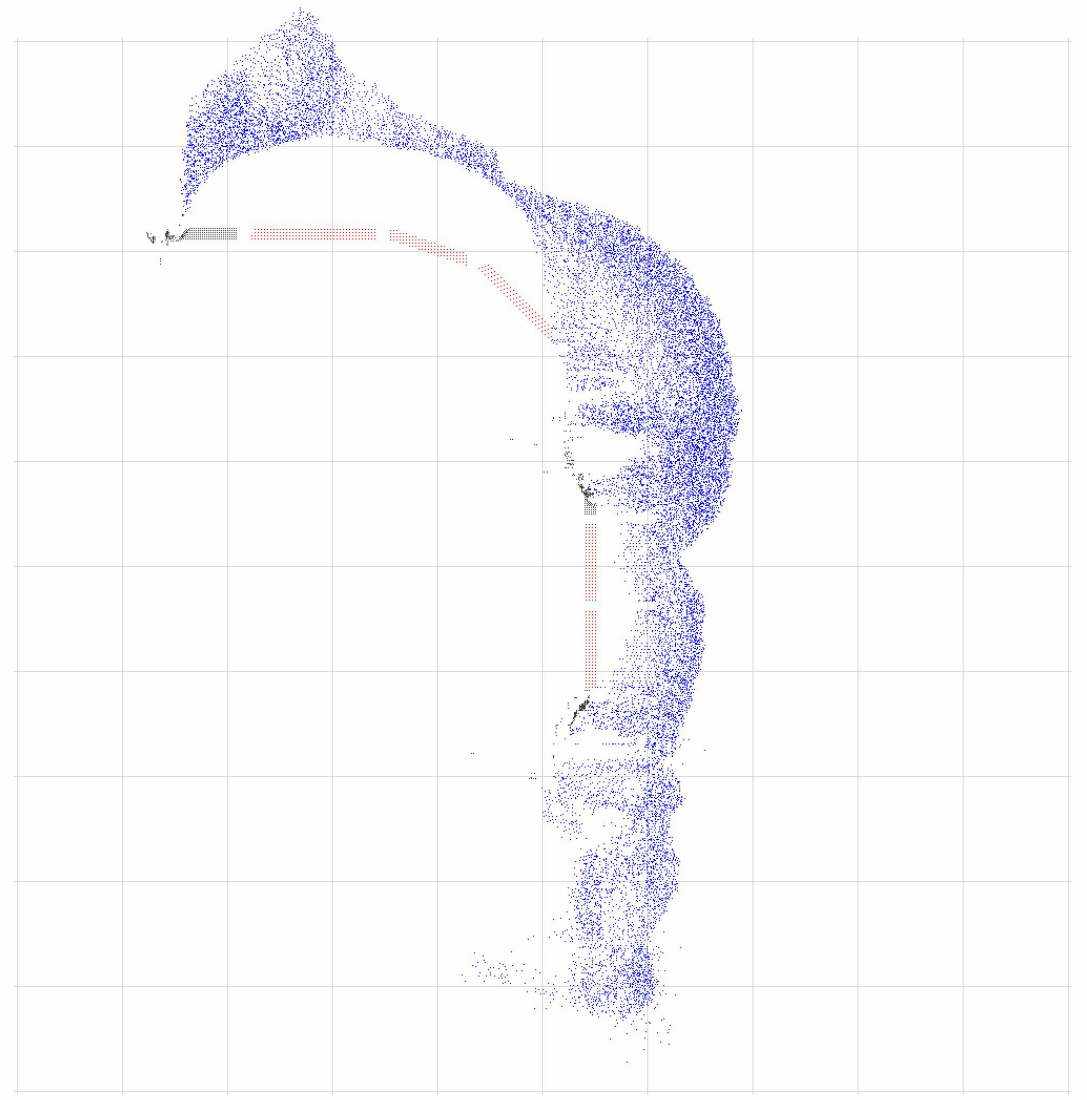

Figure 3: Time step 840 of the Historical Scenario: Zulu (blue) agents break through the British (red) line on the right flank and also through the positions of the NNC (gray). Individual NNC agents can be seen retreating from their positions.

This situation is simulated accurately by the model as depicted in Figure 1. The Zulu center and left wing can be seen to be bunching along the leading edge as the front ranks drop prone to avoid the British fire but the rear ranks continue to press forward. The Zulu opposite the NNC positions have advanced further because the NNC have few ineffective firearms. The right wing (or "right horn") of the Zulu army is not yet engaged and is moving to outflank the British line.

An interesting feature of agent-based models is that macro-behaviors often emerge unexpectedly. Figure 1 shows that the leading Zulu regiments have assumed a distinct "crescent" formation even though the rule sets for individual agents do not force them into this formation. Further details on emergent behavior in similar models can be found in (Hawick, Scogings, and James 2007).

Historically the British managed to hold the Zulu at bay for some time but units farthest from the ammunition resupply wagons in the camp began to run short of ammunition. The initial shortage appears to have been on the British right flank and the model accurately simulates this situation as shown in Figure 2. Due to the shortage of ammunition, the British agents at the end of the line are unable to fire as often and the Zulu seize the opportunity to rush forward and overwhelm this part of the British line.

Some time later, other British formations also run short of ammunition and the Zulu break into these positions as well as through the positions of the poorly armed NNC. This situation is depicted in Figure 3. 


\section{Scogings and Hawick}

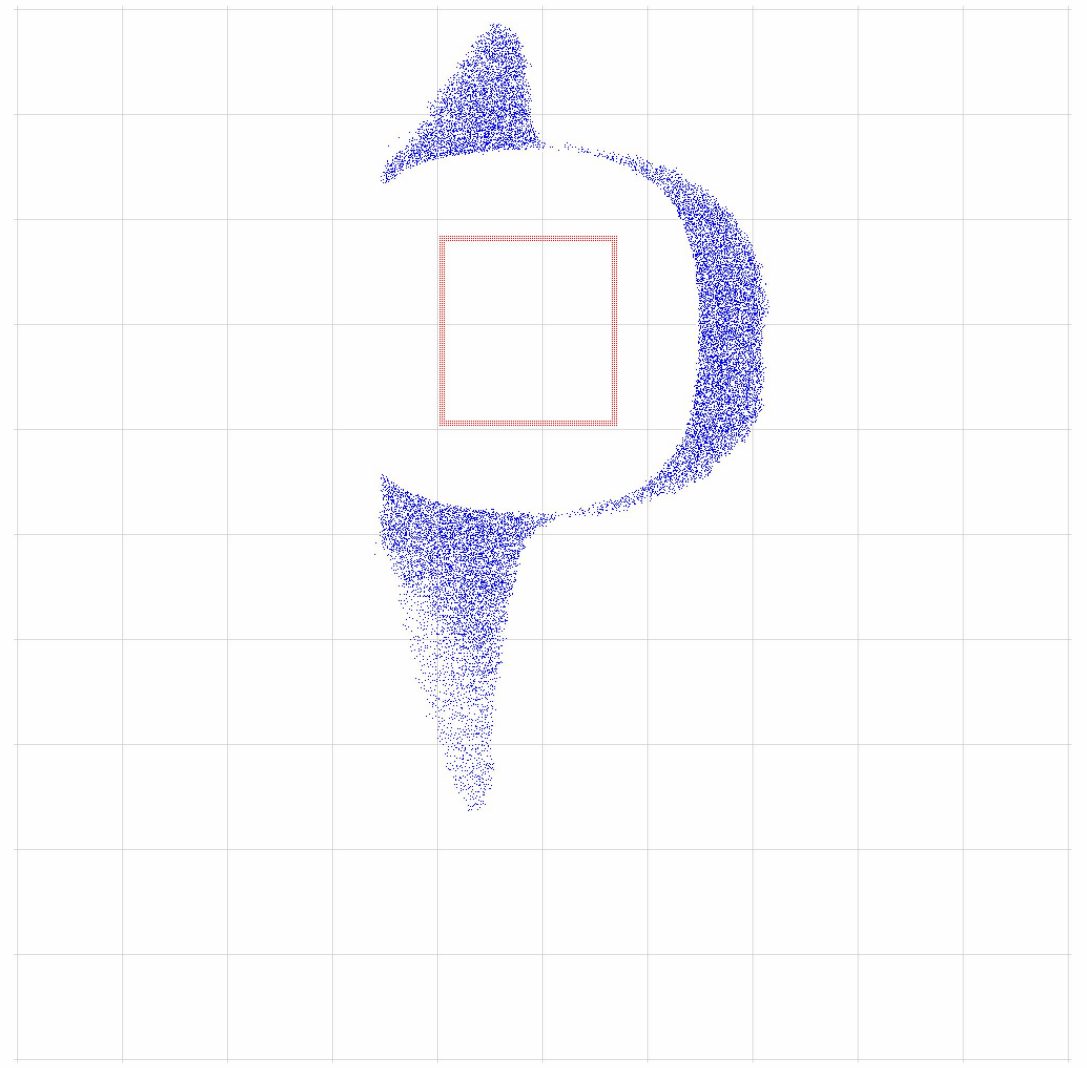

Figure 4: Time step 1360 of the Alternative Scenario : the Zulu (blue) have taken some time to move into position around the British (red) square and both the left and right wings are still moving into position. British troops are all close to the ammunition supply ensuring that the rate of fire is not reduced. There are no NNC troops present.

The model again accurately simulates the historical battle in that the center of the British line is able to hold out for longer than the other positions.

The model provided a good simulation of the historical battle. Not only was the final outcome accurate but the sequence of the various stages of the battle (as described above) was also correctly simulated.

\section{THE ALTERNATIVE SCENARIO}

It has been demonstrated that the model can accurately simulate the situations and outcome of the historical Battle of Isandlwana. The model can now be used unchanged to test an alternative scenario for the battle. Recent publications (Knight and Castle 2004; Snook 2006) have listed a number of problems with the historical British deployment including:

- the British line was too long and spread out - due to part of the garrison (the right of the line) moving to reinforce the troops that had become involved on the previous day with the Zulu diversion.

- the British line could be outflanked - as a consequence of the movement described above. 


\section{Scogings and Hawick}

- British troops were in open skirmish order - standard tactics in colonial warfare. It had been shown to be very effective in running fire-fights over broken terrain against elusive enemies.

To this list can be added a personal observation of the authors, namely that the NNC should not have been deployed at all. Clearly they were unreliable and poorly armed troops and of little use in a set piece defensive position.

The alternative scenario sets out to rectify the problems identified above. The model parameters are unchanged but the British troops are formed into a square in close formation and the NNC are removed from the scenario. The Zulu forces are identical to the historical scenario.

One of the stages of the alternative simulation is depicted in Figure 4. The Zulu have taken some time to move into position around the British (red) square and both the left and right wings are still moving into position. British troops are all close to the ammunition supply ensuring that the rate of fire is not reduced and no NNC troops are present.

The situation in Figure 4 illustrates a new problem for the Zulu in that the British square is much smaller than the British historical line. This means that the Zulu actually have difficulty in bringing all their agents to bear as regiments interfere with the approach of other regiments causing delays in forming the circle around the British position.

The final result of the alternative scenario was that Zulu casualties rose to a point where the Zulu would probably have abandoned the attack - as happened historically at both the battles of Rorke's Drift and Ulundi.

\section{DISCUSSION AND FUTURE WORK}

This paper has described an experiment in simulating combat using an agent-based model. The aims of this experiment were:

- to demonstrate that it is possible to simulate an historical battle by employing agents to represent every individual involved.

- to show the efficiencies of hand-coding an agent-based model and to incorporate techniques to avoid wasting time on the traditional search for individual neighbors.

- to fine tune the parameters of the model in order to accurately simulate the historical battle and then to use the model with the parameters unchanged in order to analyze the feasibility of a reasonable alternative to the historical scenario.

The Battle of Isandlwana was selected as a good historical battle to simulate because it avoided additional challenges (such as terrain effects, different weaponry, etc) and was also a battle in which alternative British formations had been suggested but never analyzed.

Our agent-based model has successfully achieved these goals. It not only produced the correct historical outcome but also accurately simulated the various stages of the historical battle. And the unchanged model then demonstrated that a change in British starting formation would probably have lead to a different outcome to the battle.

This approach of starting from a (historically) detailed initial configuration pattern of agents, then running the model from minor perturbations, appears to be a generally useful one. As well as identifying emergent spatial patterns that are highly robust against changes to the initial conditions, this approach is also a potentially useful one for examining the stability and likelihood of the outcomes. For some models and scenarios there will be fixed points in the outcomes that are seemingly inevitable regardless of different military decisions made at the time. Other models and scenarios can be judged more fluid or unstable using this approach.

We believe a key factor in the success of this sort of model is the high (and realistic) number of agents. Many of the patterns and structures seen in the agent battlefield would only emerge on the size and length 


\section{Scogings and Hawick}

scales reported. The individual agent rules are simple, but bringing them together in large enough numbers leads to macroscopic phenomena that are not necessarily easily predictable.

Future work in this area will include investigating military scenario models with a higher number of agents; models with terrain effects (hills, trenches, etc); models in which agents can decide on (and perform) complicated movements; and models with a range of weaponry such as artillery, tanks, aircraft, etc.

\section{APPENDIX}

\section{British forces (total of 1,691 men)}

11th/7th Brigade, Royal Artillery - 10 men

N/5th Brigade, Royal Horse Artillery - 72 men

1st/24th Regiment (5 companies) - 416 men

2nd/24th Regiment (1 company) - 175 men

Natal Native Horse (5 troops) - 245 men

Imperial Mounted Infantry - 28 men

Newcastle Mounted Rifles - 18 men

Natal Mounted Police - 34 men

Natal Carbineers - 28 men

1/1st Natal Native Contingent - 245 men

1/3rd Natal Native Contingent - 211 men

2/3rd Natal Native Contingent - 209 men

\section{Zulu forces (total of $\mathbf{1 9 , 0 0 0}$ men engaged)}

Right horn: uDududu, iSangqu, iMbube, uNokhenke regiments $-4,000$ men

Center: uMcijo, uMxhapho regiments - 9,000 men

Left horn: uMbonambi, iNgobamakhosi, uVe regiments $-6,000$ men

Reserve (not engaged): uThulwana, iNdluyengwe, iNdlondlo, uDloko regiments $-4,000$ men

\section{REFERENCES}

Cares, J. R. 2002, December. "The Use of Agent-Based Models in Military Concept Development". In Proceedings of the 2002 Winter Simulation Conference, edited by E. Yücesan, C. H. Chen, J. L. Snowdon, and J. M. Charnes, 935-939. Piscataway, New Jersey: Institute of Electrical and Electronics Engineers, Inc.

Caristi, G., K. P. Rybakowski, and T. Wessoler. 1992. "Persistence and Spatial Patterns in a One-PredatorTwo-Prey Lotka-Volterra Model with Diffusion". Annali di Matematica pura ed applicata CLXI (IV): 345-377.

Cioppa, T. M., T. W. Lucas, and S. Sanchez. 2004, December. "Military Applications of Agent-Based Simulations". In Proceedings of the 2004 Winter Simulation Conference, edited by R. G. Ingalls, M. D. Rossetti, J. S. Smith, and B. A. Peters, 171-180. Piscataway, New Jersey: Institute of Electrical and Electronics Engineers, Inc.

Garcia, V., M. Birbaumer, and F. Schweitzer. 2011. "Testing an agent-based model of bacterial cell motility: How nutrient concentration affects speed distribution". The European Physical Journal B 82 (3-4): 235-244.

Gerdelan, A. P. 2011. Fuzzy Motion Controllers and Hybrids. Ph. D. thesis, Computer Science, Massey University, Albany, New Zealand.

Hawick, K. A., C. J. Scogings, and H. A. James. 2007, December. "Spatial Emergence of Genotypical Tribes in an Animat Simulation Model". In Proceedings of the 2007 Winter Simulation Conference, 


\section{Scogings and Hawick}

edited by S. G. Henderson, B. Biller, M.-H. Hsieh, J. Shortle, J. D. Tew, and R. R. Barton, 1216-1222. Piscataway, New Jersey: Institute of Electrical and Electronics Engineers, Inc.

Hawick, K. A., C. J. Scogings, and H. A. James. 2008, October. "Defensive Spiral Emergence in a Predator-Prey Model". Complexity International 12 (msid37): 1-10. ISSN 1320-0682.

Husselmann, A., and K. Hawick. 2011, 14-16 Dec. "Simulating Species Interactions and Complex Emergence in Multiple Flocks of Boids with GPUs". In Proc. IASTED International Conference on Parallel and Distributed Computing and Systems (PDCS 2011), edited by T. Gonzalez, 100-107. Dallas, USA.

Ilachinski, A. 2004. Artificial War - Multiagent-Based Simulation of Combat. World Scientific. ISBN 981-238-834-6.

Jim, K., and C. Giles. 2000. "Talking helps: evolving communicating agents for the predator-prey pursuit problem". Artificial Life 6 (3): 237-254.

Kaup, D. J., T. L. Clarke, R. Oleson, and L. C. Malone. 2007. "Crowd Dynamics Simulation Research". In Proc. 16th Conf. on Behaviour Representation in Modeling \& Simulation (BRIMS'07), Orlando, FL, USA, 173-180.

Knight, I., and I. Castle. 2004. Zulu War. Osprey Publishing. ISBN 1-84176-858-8.

Laband, J., and P. Thompson. 2000. The Illustrated Guide to the Anglo-Zulu War. University of Natal Press, Pietermaritzburg, South Africa. ISBN 086-980-973-3.

Lanchester, F. W. 1916. Aircraft in Warfare: The Dawn of the Fourth Arm. Constable and Company, Ltd. ISBN 9781110096466.

Macal, C. M., and M. J. North. 2006, December. "Tutorial on Agent-Based Modeling and Simulation Part 2: How to Model with Agents". In Proceedings of the 2006 Winter Simulation Conference, edited by L. F. Perrone, F. P. Wieland, J. Liu, B. G. Lawson, D. M. Nicol, and R. M. Fujimoto, 73-83. Piscataway, New Jersey: Institute of Electrical and Electronics Engineers, Inc.

Procaccia, I. 1988, June. "Universal properties of dynamically complex systems: the organisation of chaos". Nature 333:618-623.

Reynolds, C. 1987. "Flocks, herds and schools: A distributed behavioral model". In SIGRAPH '87: Proc. 14th Annual Conf. on Computer Graphics and Interactive Techniques, edited by M. C. Stone, 25-34. ACM.

Scogings, C., and K. Hawick. 2008, February. "Altruism Amongst Spatial Predator-Prey Animats". In Proc. 11th Int. Conf. on the Simulation and Synthesis of Living Systems (ALife XI), edited by S. Bullock, J. Noble, R. Watson, and M. Bedau, 537-544. Winchester, UK: MIT Press.

Scogings, C. J., K. A. Hawick, and H. A. James. 2006, September. "Tools and Techniques for Optimisation of Microscopic Artificial Life Simulation Models". In Proceedings of the Sixth IASTED International Conference on Modelling, Simulation, and Optimization, edited by H. Nyongesa, 90-95. Gabarone, Botswana.

Settembre, G. P., P. Scerri, A. Farinelli, K. Sycara, and D. Nardi. 2008, May. "A Decentralized Approach to Cooperative Situation Assessment in Multi-Robot Systems". In Proc. of 7th Int. Conf. on Autonomous Agents and Multiagent Systems (AAMAS 2008), edited by Padgham, Parkes, Muller, and Parsons, 31-38. Estoril, Portugal.

Snook, M. 2006. How can man die better: The secrets of Isandlwana revealed. Greenhill Books, London. ISBN 978-1-85367-656-7.

Standish, R. K. 2001. "On Complexity and Emergence”. Complexity International 9:1-6.

Thangiah, S., O. Shmygelsaka, and W. Mennell. 2001. "An agent architecture for Vehicle routing problems". In Proc 2001 ACM Symposium on Applied Computing, 517-521. Las Vegas, USA.

Thengvall, B., and F. Glover. 2009, December. "A Framework for the Optimization and analysis of AgentBased Models". In Proceedings of the 2009 Winter Simulation Conference, edited by M. D. Rossetti, R. R. Hill, B. Johansson, A. Dunkin, and R. G. Ingalls, 1737-1744. Piscataway, New Jersey: Institute of Electrical and Electronics Engineers, Inc. 


\section{Scogings and Hawick}

Thompson, P. S. 2006, 27 August. Black soldiers of the Queen: the Natal Native Contingent in the Anglo-Zulu War. University of Alabama Press.

Trautteur, G., and R. Virgilio. 2003, 9-11 June. "An Agent-Based Computational Model for the Battle of Trafalgar: A Comparison Between Analytical and Simulative Methods of Research". In Proc. Twelfth Int. Workshop on Enabling Technologies: Infrastructure for Collaborative Enterprises (WETICE'03), edited by S. Kawada, 377-382. Linz, Austria.

\section{AUTHOR BIOGRAPHIES}

CHRIS SCOGINGS is an Associate Professor (equivalent of Reader in the UK) at Massey University in Auckland, New Zealand. He has developed agent-based models for a range of research activities including predator-prey simulations, brain neuron simulations, termite colony simulations and others. He is mainly interested in the use of agent-based models in applied settings and developing techniques to increase the efficiency of agent-based models. His email address is C.Scogings@massey.ac.nz.

KEN HAWICK is Professor of Computer Science at Massey University in Auckland, New Zealand. Hawick's research interests are in quantitative metrics and software tools for studying, simulating and modeling complex systems. His email address is K.A.Hawick@massey.ac.nz and research group web pages are at http://complexity.massey.ac.nz. 